\title{
試験燃焼炉による微粉炭多量吹き込み時の レースウェイ内燃焼挙動とガス流れ変化
}

\author{
有山 達郎*・佐藤 道貴*・村井 亮太*・宮川 一也*2・野沢＼cjkstart健太郎*2・辰條 綱雄*2 \\ Combustion Behavior and Gas Flow Change in Raceway at \\ Massive Coal Injection in Experimental Furnace \\ Tatsuro Ariyama, Michitaka Sato, Ryota Murai, Kazuya Miyagawa, Kentaro Nozawa and Tsunao Kamijo
}

Synopsis : Hot model experiments were carried out to clarify the combustion behavior in the raceway and the gas flow changes nearby the raceway at the massive coal injection into the blast furnace. From the experimental results, it was found that the location of maximum temperature in the raceway agrees with the peak position of the $\mathrm{CO}_{2}$ gas composition and it tends to move toward the tuyere when the amount of volatile matter carried by the injected coal increases. The combustion efficiency was influenced by the volatile matter content of the injected coal and the oxygen enrichement had little effect on the combustion efficiency. The heat load to the wall of the hot model increased by the approach of the maximum temperature position toward the tuyere and it decreased by the reduction of ash content in the coal. It was observed that the shell layer was formed at the depth of the raceway. Then, it was estimated that the peripheral gas flow was intensified and the heat load to the wall increased due to the formation of the shell layer. These tendencies were confirmed by the mathematical simulation on the gas flow.

Key words : ironmaking ; blast furnace ; pulverized coal injection ; raceway ; pulverzed coal combustion ; hot model.

\section{1. 緒言}

高炉への微粉炭吹き込みは製銑工程での合理化のみなら ず，今後のコークス炉老朽化への有力な対策としても重要 な技術として考えられ，200kg/tを超える多量吹き込みが， 国内外を問わず志向されつつある。しかし，長期安定操業 を目指すうえでは依然として課題も残されている。従来よ り, 微粉炭吹き込み量を増加させるに伴い, 炉頂温度の上: 昇, 炉内圧損の増加が報告され(1)2), これらの問題に関して は, 装入物分布, 酸素富加条件の適正化によって徐々に克 服されつつあるが3)4, $150 \mathrm{~kg} / \mathrm{t}$ 以上の微粉炭吹き込み量では, さらに炉下部に関わる問題も指摘されている。例えば，上 條ら ${ }^{5}$ は微粉炭吹き込み量が $200 \mathrm{~kg} / \mathrm{t}$ に接近すると, 炉下部 圧損の増大と同時に，炉下部熱負荷の上昇が認められ，多 量吹き込み操業を継続する上で炉下部周辺流制御が重要で あると報告している。このような観点より，微粉炭多量吹 き込みの長期安定操業を達成する上で，レースウェイ近傍 での通気性, 熱負荷変化なども含めた炉下部固有の現象の 解明と対策が必要と思われる。

従来より，燃焼ホットモデルなぼにより，微粉炭燃焼に 力点を置いた研究はなされているが677), 微粉炭吹き込み時 のレースウェイ内燃焼挙動とガス流れ変化，炉下部におけ
る熱負荷などを総命的に検邻した研究は少ない。そこで， 本研究では小型のコークス充填屏型試験燃烧灯を朋いて微 粉炭吹き込みに伴うレースウエイ内燃烧举動の变化を調査 し，さらにコークス層を降トできる大型式験燃烧灯により

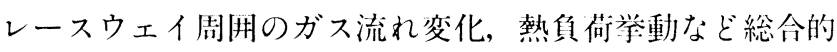
な検討を行った。その結果, 微粉炭多昂吹き込みの产期安 定操業を実現するトで，重要な知胃が得られたので報告す る。

\section{2. 実験方法}

\section{$2 \cdot 1$ 実験装置}

本研究では, 前述のように二種類の試験燃烧炉を用いた。 小型燃焼試験灯 i I は既報の設借 ${ }^{6)}$ と间一で幅 $0.4 \mathrm{~m}$, 奥行き $0.6 \mathrm{~m}$ のコークス充塡層と内径 $0.09 \mathrm{~m}$ のブローパイプ部から 構成され, 羽山径は0.065mである。今问の試験では妆山先 端から $0.27 \mathrm{~m} の$ 仿置の1:部から微粉荻吹き込み树のランスを 1 本設置した。また，コークス充塡層の列川対面側からが スサンプリング, 温度測定用の水冷プローブを挿入できる。 さらに，ブローパイプ部と排ガスに界管に㧍测定孔を設 けた。

次に試験灯 II をFig. 1 にホす。献さ $2.5 \mathrm{~m}$, 奥行き $1.9 \mathrm{~m} の$ 
扇形の炉であり，内烽 $0.08 \mathrm{~m} の$ 妆川1 1 本を有する。熱風炉は

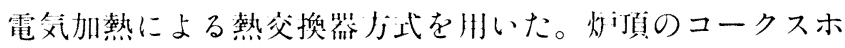
ッパーには超暗波レベル郭を没け，卜部コークスホッパー のレベル変化からユークス消費速度を涪测できる。また， この燃烧灯の大きな特徵として火iト部につめ川砂の充塡層

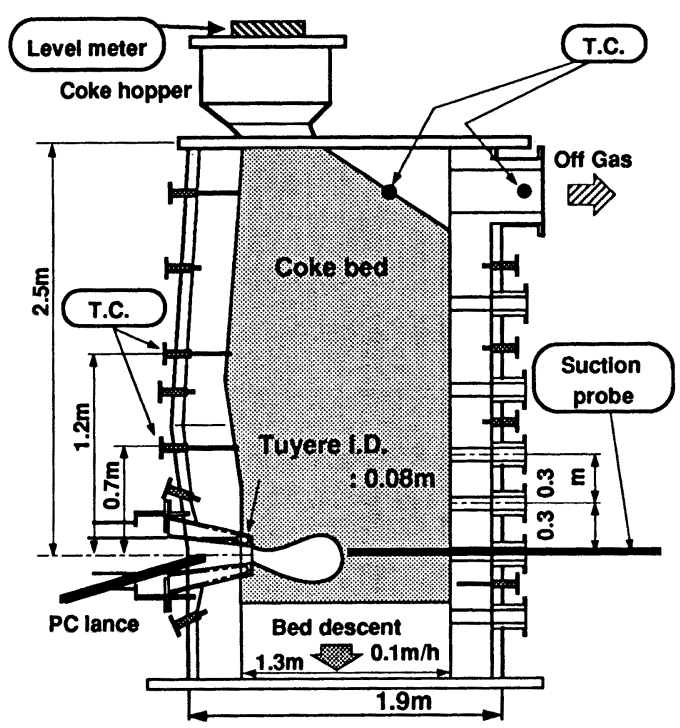

Fig. 1. Experimental furnace II.

Table 1. Condition of experimental furnace.

\begin{tabular}{l|l|l}
\hline & Furnace I & Furnace II \\
\hline Blast flow rate & $350 \mathrm{Nm}^{3} / \mathrm{h}$ & $560 \sim 720 \mathrm{Nm}^{3} / \mathrm{h}$ \\
Blast temperature & $1200^{\circ} \mathrm{C}$ & $1050^{\circ} \mathrm{C}$ \\
Oxygen content & $21 \mathrm{vol} \%$ & $21 \sim 27 \mathrm{vol} \%$ \\
Coal injection rate $(\mathrm{PCR})$ & $6 \overline{\mathrm{kg}} / \mathrm{h}(200 \mathrm{~kg} / \mathrm{t})$ & $72,144 \mathrm{~kg} / \mathrm{h}(200 \mathrm{~kg} / \mathrm{t})$ \\
Lance position from tuyere nose & $0.27 \mathrm{~m}$ & $0.17 \sim 0.34 \mathrm{~m}$ \\
\hline
\end{tabular}

Table 2. Composition of pulverized coal. d.b. : dry base

\begin{tabular}{c|rrr|rrrrrr}
\hline \multirow{2}{*}{ Coal } & \multicolumn{3}{|c|}{$\begin{array}{c}\text { Proximate analysis } \\
\text { (d.b.mass\%) }\end{array}$} & \multicolumn{4}{c}{ Ultimate analysis (d.b.mass\%) } \\
\cline { 2 - 10 } & V.M. & Ash & F.C. & C & H & N & S & O \\
\hline A & 34.9 & 8.5 & 56.6 & 73.9 & 4.8 & 1.6 & 0.4 & 10.8 \\
B & 30.9 & 1.5 & 67.6 & 84.6 & 5.0 & 1.0 & 1.0 & 6.9 \\
C & 24.3 & 7.9 & 67.8 & 78.9 & 4.3 & 1.6 & 0.6 & 6.7 \\
D & 11.2 & 0.5 & 88.3 & 89.3 & 3.8 & 2.4 & 1.6 & 2.4 \\
E & 33.2 & 9.8 & 57.0 & 73.3 & 4.7 & 1.8 & 0.6 & 9.8 \\
F & 42.3 & 3.4 & 54.3 & 76.8 & 5.7 & 1.6 & 0.4 & 12.2 \\
\hline
\end{tabular}

を設け,この砂を底部のロータリーフィーダーで切り出し, 充塡層全体のコークスを降下させ, 炉芯の更新を模擬でき るような構造となっている。さらに, 羽口対面側から 3 ケ 所のレベル (羽口中心, 羽口上 $0.3 \mathrm{~m}, 0.6 \mathrm{~m}$ ) で水冷のサン プリングプローブを挿入でき，炉壁部には熱電対を設置し てある。

\section{$2 \cdot 3$ 実験条件および実験方法}

試験炉 I, IIの実験条件をTable 1 に示す。試験炉 I では LPGの燃焼ガスに酸素を混合して, 所定酸素濃度の熱風と し, 炉内には粒径約 $25 \mathrm{~mm}$ のコークスを充眞した。試験炉 II では送酸量一定の条件の下, 酸素濃度を21～27vol\% と変更 した。使用コークス粒径は約 $17 \mathrm{~mm}$ である。また用いた微粉 炭の性状をTable 2 に示す。粒度はいずれも $74 \mu \mathrm{m}$ 以下 $80 \%$ である。

試験炉Ｉではレースウエイ内温度分布を詳細に測走する ために，光ファイバーをプローブ先端の孔から抻入し，そ の光信号を高速の放射温度計に導入して温度計測を行った。 その構成闵をFig. 2 に示す。従来では,レースウェイ内の温 度測定は熱電対あるいは 2 色温度計などで行われてきたが, レースウェイ内は高温の酸化雲囲気であり，局所的な精度 の高い直接測走は困難であった。この光ファイバーは消耗 型であり，レースウェイ内の高温部で先端が溶融しても， 水冷プローブ内を通じて逐次, 光ファイバーを送り迄み, 瞬間的に光信号を受信することで目的部位の温度の測走が 可能である。さらに，その際，Fig. 2 に亦すように，プロー ブ先端の光ファイバー用の孔を羽口中心軸トに設定し，プ ローブを $90^{\circ}, 180^{\circ}$ と问転させることによって先端孔隹置を 高さ力向に変更し，レースウエイ内高さ力们温度分布を求 めた。

\section{3. 実験結果}

\section{3・1 レースウェイ内温度およびガス組成分布}

Fig. 3 は試験炉Iにおけるレースウェイ内の 2 次元的な温 度分布と羽口中心軸上のガス組成分布測定結果を示寸。こ の温度は光ファイバーと放射温度計による計测によるため,

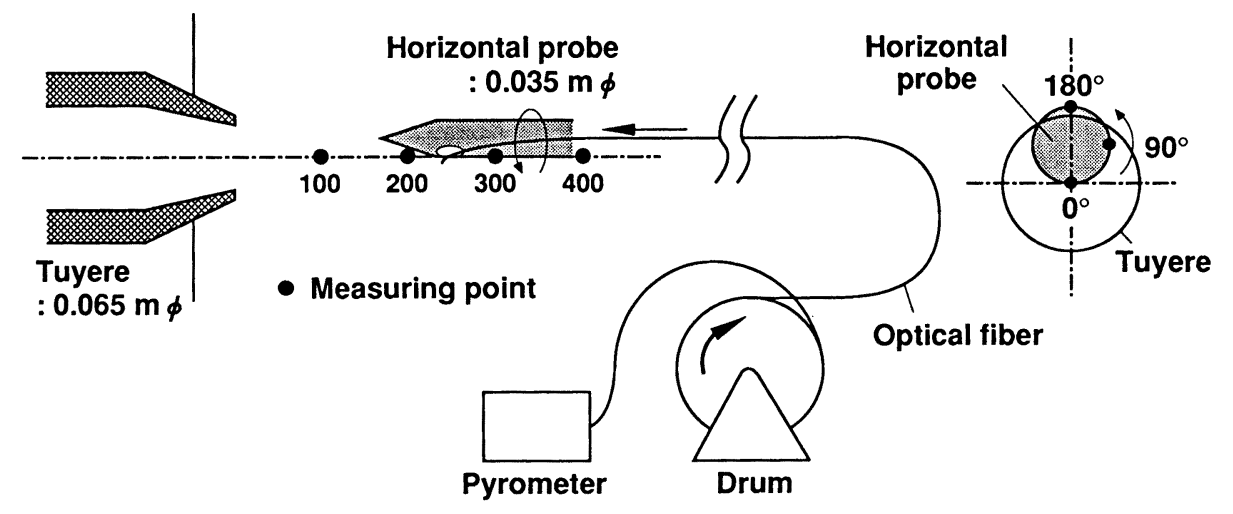

Fig. 2. Temperature measuring device by optical fiber. 
(a) All coke

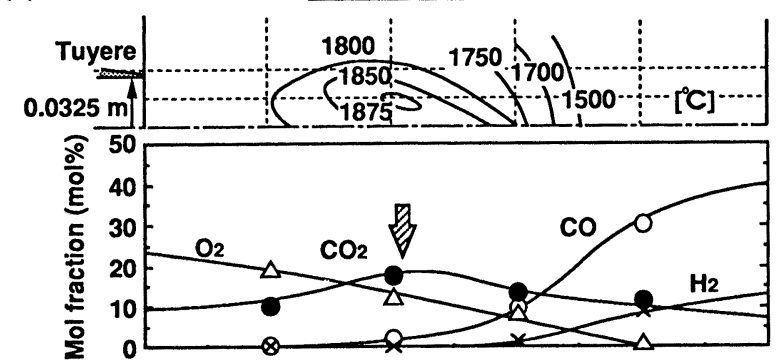

(b) PCR : $200 \mathrm{~kg} / \mathrm{t}$

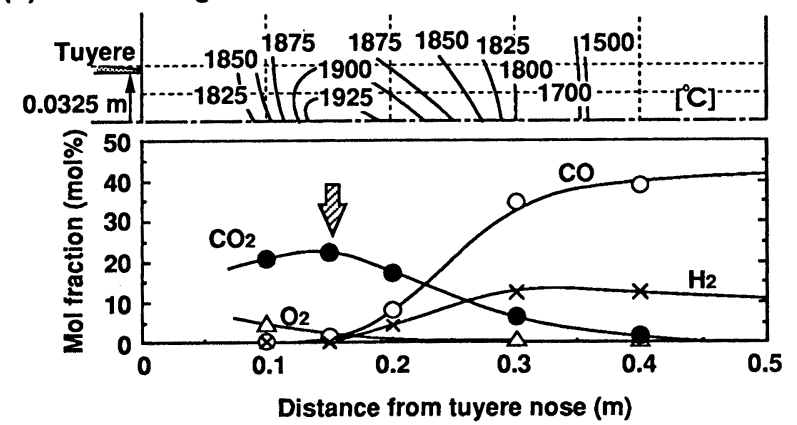

Fig. 3. Temperature and gas composition distribution in raceway.

輝炎の温度を示しているものと考えられるが，基本的にそ の温度場決定に支配的なガス温度に対応したものと考えら れる。本結果によると，オールコークス時には最高温度出 現位置が羽口中心よりやや上方に現れる。そして，200kg/ tの微粉炭吹き込み時には, その位置は羽口中心軸上に移り, オールコークス時より羽口側に接近する。同時に示したガ ス組成分布では, 微粉炭吹き込みの場合, 酸素濃度が羽口 先で急減し, $\mathrm{CO}_{2}$ 濃度のピークはオールコークス時より羽口 に接近する。そしてこのピーク位置はオールコークス, 微 粉炭吹き込みを問わず，いずれの場合も上述の最高温度出 現位置とほぼ一致する。

通常，レースウェイ内に流入するコークスあるいは微粉 炭などの燃料が酸素を消費し, $\mathrm{CO}_{2}$ を生成するとともに熱を 放散する。よって, $\mathrm{CO}_{2}$ 濃度のピーク位置が燃焼発熱反応の 最も活発な最高温度位置に対応したと考えられる。以下, このピーク位置を燃焼焦点とする。また，オールコークス 時には，レースウェイ上部から流入する高温のコークスと 酸素の接触によってガス組成，温度分布が決定されるのに 対し, 微粉炭吹き込み時には, 微粉炭の燃焼初期に生じる 揮発分の燃焼速度が非常に速く，急速に周囲の酸素を消費 するため，オールコークス時より羽口側にこの燃焼焦点を 接近させることになったと考えられる。

\section{$3 \cdot 2$ 燃焼焦点と炭種の関係}

次に燃焼炉II を用い, 微粉炭吹き込み量と炭種を種々変 更し，燃焼焦点の動きを検討した。Fig. 1 に示したように， 羽口対面からプローブを挿入して, 羽口中心軸上のガス組 成を測定し, $\mathrm{CO}_{2}$ 濃度のピークとなる燃焼焦点を求めた。従

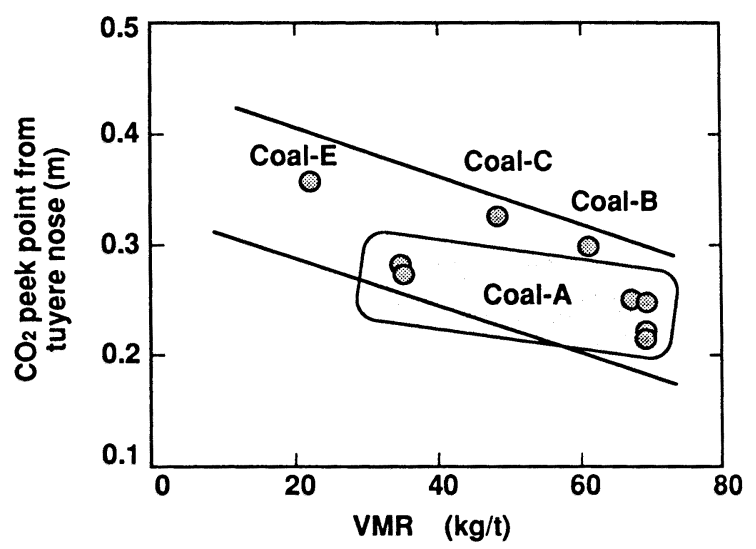

Fig. 4. Effect of volatile matter on $\mathrm{CO}_{2}$ peak point in raceway.

来の微粉炭燃焼实験によると，吹き込み沽後の燃焼反応々 しては基本的に，不炭の急速熱分解によって生に゙た揮発分 の燃焼が主体になる ${ }^{8)}$ 。ャーの燃狫速度は遅く,レースウ エイ内では捙発分の燃焼がガス組成, 温度分布を大きく支 配すると考えられる。よって，捕発分投入量と燃焼焦点と の関係を調查した。

Fig. 4 に燃焼焦点と搏発分投入㫣VMR (VMR $(\mathrm{kg} / \mathrm{t})=$ $\operatorname{VM}(\%) \times \operatorname{PCR}(\mathrm{kg} / \mathrm{t}) \times 100)$ との関係をホす。炭種Aにつ いては微粉炭吹き込み量を $100 \mathrm{~kg} / \mathrm{t}, 200 \mathrm{~kg} / \mathrm{t}$ と変更した結 果である。本汹で明らかなように，捕発分投入量が多いほ ぞ燃焼焦点は羽山側に接近する傾问が垫められる。すなわ ち，掉発分の高い荻種ほぼ，また间一若種では微粉炭吹き 込み量が增えるほぼ酸素の消費速度がリり，燃焼焦点， すなわちレースウェイ内の最涪温度位置は妆山側に接近す る。

\section{$3 \cdot 3$ 微粉炭燃焼率}

燃焼灯 II 朋い，コークス消費速度から微粉炭の燃焼率 を推定した9)。微粉岑吹き込みによってコークス消費量が減 少するが，その低ト荲に相当する酸素消費が微粉炭中の炭 素の燃焼, 寸なわち $\mathrm{C}+1 / 2 \mathrm{CO}_{2}=\mathrm{CO} の$ 応によって行われ たとして計算した。ここで，微粉菼中の $\mathrm{H}_{2}$ は燃焼の収支に 関·せざ，微粉炭中の酸素は微粉获中の炭素と優先的に反 応するものとした。結果的にこのようにして求めた燃焼 率は不炭中の可燃分の消費摔になる。

この方法で求めた燃焼率と炭種の関係をFig. 5 に示す。揮 発分の高い炭種では本結果で明らかなようにレースウエイ 内で高い燃焼率を達成できる。またFig. 6 には酸素富化, 微 粉炭吹き込みランス位置と燃狫摔との関係を示す。ランス 位置が羽日先端より $0.24 \mathrm{~m} の$ 場合, 酸素富化によって燃焼率 は徐々に后上するが，酸素富化 $6 \%$ で燃焼率向上は 5 \% 程 度であり，その効果は顕著でない。本笑験の範井では全体 にランス位置の影響は明確でないが，燃焼開始点はランス 位置からの距離によって規定されると考えられ6), ランス位 置変更により微粉炭の到達燃烧摔は影響を受けると推測さ れる。 


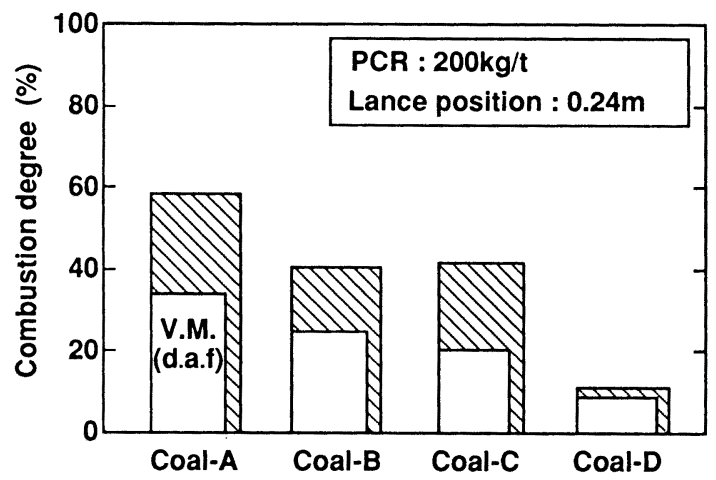

Fig. 5. Effect of coal species on combustion degree (Lance position: distance between lance tip and tuyere nose).

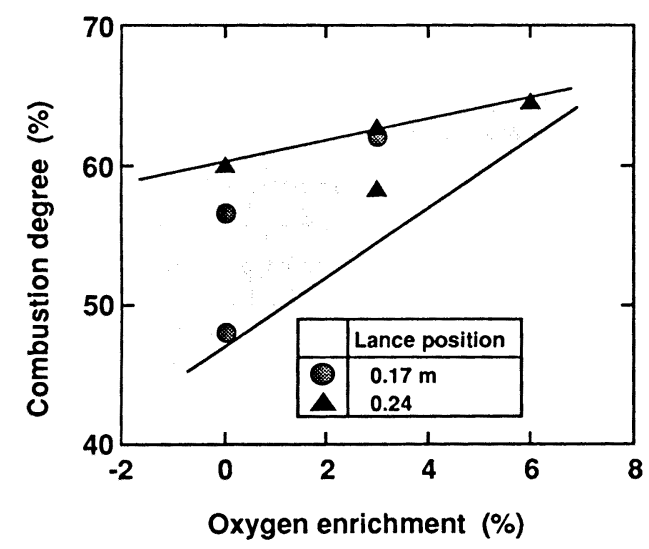

Fig. 6. Effect of oxygen enrichment and lance position on combustibility (Lance position: distance between lance tip and tuyere nose).

\section{$3 \cdot 4$ 燃焼焦点と炉体熱負荷}

揮発分投入量は燃狫焦点の位㯰を大きく左右する。高揮 発分の炭種選択は活い燃烧率を期街できるが，同時に燃焼

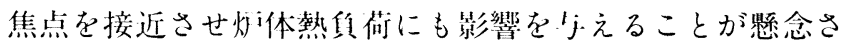
れる。試験炉 II を州いて燃狫焦点と灯体熱負街との関係を

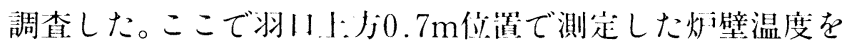
炉体熱負荷の指標とした。

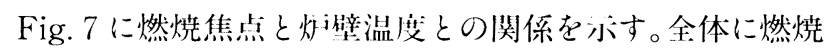
焦点が羽川に接近すると炕壁温度が、早することがわかる。 例えば，オールコークスでは，燃烧焦点は $0.46 \mathrm{~m}$, 炉壁温度

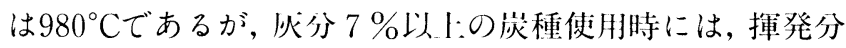
$35 \%$ 微粉炭を吹き込むことによって燃焼焦点は $0.28 \mathrm{~m}$ に接 近すると同時に, 灯壁温度は約 $200^{\circ} \mathrm{C}$ 上昇する。また, 注目 すべきこととして灯壁温度は微粉炭中の灰分量によっても 変化する。すなわち，我分 $2 \%$ 以下の微粉炭使用時には燃 焼焦点接近に伴う炉壁温度卜算の傾的が䋸和されている。

さらに，本四には酸素富化の影響も示したが，酸素富化 により燃焼焦点がきく接近しても啫温度の上昇は小さ い。これは酸素富化により, 羽山ト部の熱流比が増大した 結果と考えられる。よって, 酸素富化も灯下部の熱負荷上: 昇傾问を緩和する効果を持つと考えられる。

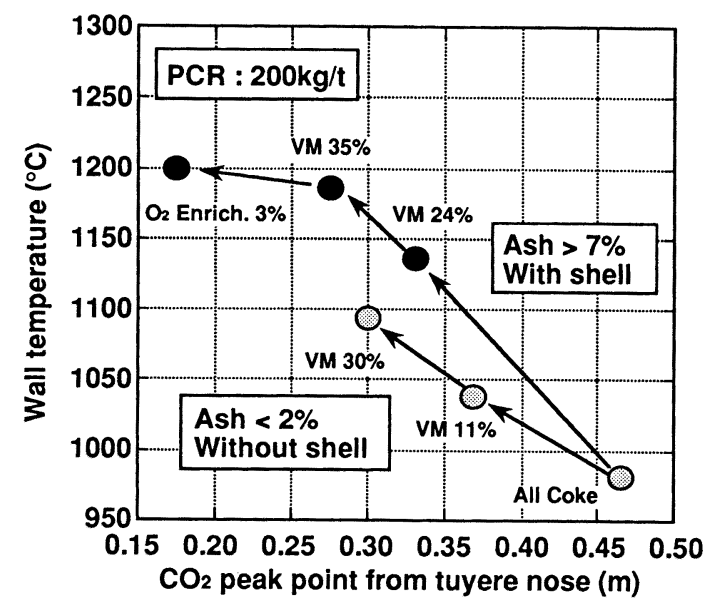

Fig. 7. Relationship between $\mathrm{CO}_{2}$ peak point and wall temperature.

\section{4. レースウェイ近傍の通気性変化}

\section{$4 \cdot 1$ 微粉炭吹き込みに伴うシェル層の形成}

$200 \mathrm{~kg} / \mathrm{t}$ t超える微粉炭多量吹き込み時には炉頂から未燃 のチャーが排出されるなど, 燃焼に関わると思われる問題 も報告されている ${ }^{4)}$ 。よって, 微粉炭の燃焼率を最大限, 確 保することが基本であるが, 安定操業達成のためには緒言 で述べたように, 高炉下部における通気性の維持, 熱負荷 抑制も同時に必要と考えられる。しかし，既に明らかにな ったように燃焼の促進を図ること, 例えば高揮発分炭の使 用は燃焼点の羽口側への接近を生じ, 熱負荷の上昇を招く。 ただし，3・4で述べたように使用炭の灰分も熱負荷に影響 を与えることから，レースウェイ近傍のガス流れを決定す る通気性と石炭灰分の関係にも注目する必要がある。

以上の観点から, 試験炉IIにおいて, 燃焼試験終了後に 解体調査を行った。本試験炉ではユークス充填層は連続的 に降下しており，レースウェイ奥の層は逐次，更新され， 実高炉に近い。炭種A, Bを使用し， $200 \mathrm{~kg} / \mathrm{t}$ の吹き込み実 験を行い, 試験終了後の炉内解体によって得られたレース ウェイ近傍の写真をFig. 8 (a), (b) に示す。灰分 $8.5 \%$ の炭 種Aの微粉炭吹き込み時には冷却後, Fig. 8 (a)に示すよj にレースウェイ周囲に白色の部分で識別される殼状の層(以 下, シェル層とする)の形成が認められた。このシェル層は ユークス粒子と微粉炭灰分由来の溶融層が一体となった通 気性不良の層と観察された。またFig. 8 (b)のように灭分 1.5 $\%$ の低灰分炭B使用時にはシェル層の形成は軽微であった。 さらに炭種 $\mathrm{A} て ゙ も ~ 100 \mathrm{~kg} / \mathrm{t}$ の吹き込み時, およびオールコー クス時にもシェル層の形成は同様に軽微であった。

これらは冷却後に認められた現象であるが，燃焼試験中 におけるシェル層の形成を検知するために, 試験炉 I で燃 焼試験中にブローパイプ部の圧力変動に注目した。微粉炭 吹き込み時のブローパイプ内の圧力の経時変化をFig. 9 に示 す。炭種は灰分 $9.8 \%$ の炭と, 灰分 $3.4 \%$ 岸である。 $\mathrm{E}$ 
Coal-A

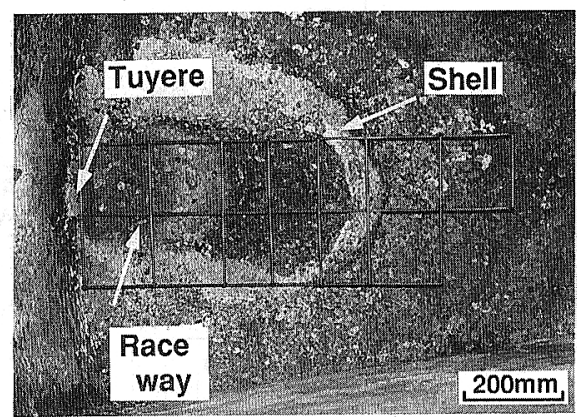

(a) With shell

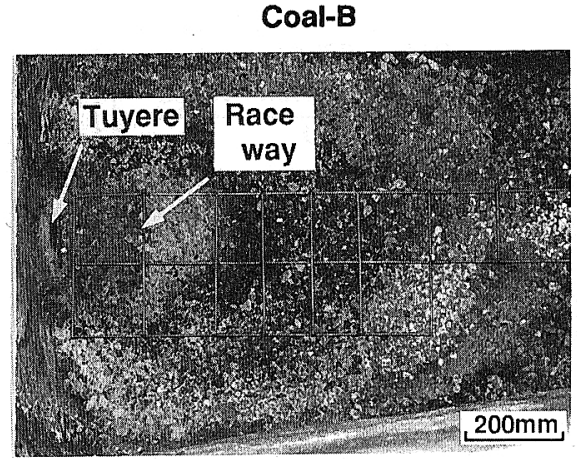

(b) Without shell

Fig. 8. Horizontal plane at tuyere level (Experimental furnace II, PCR=200kg/t).

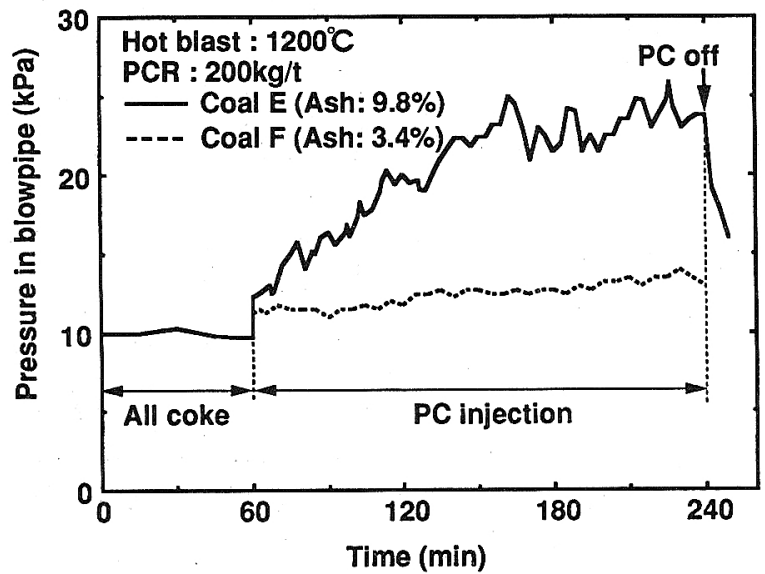

Fig. 9. Change in pressure with coal injection (Experimental furnace I).

炭使用時には微粉炭の吹き込及後から，徐々にブローパイ プ圧力は上昇し，かつ変動も大きいことがわかる。また， F炭の場合に性圧力の上昇は緩和されている。この試験炉 I でも実験終了後の炉解体時ではE炭使用の場合,試験炉 II と 同様なシェル層が認められた。このE炭の場合, 微粉炭吹き 込み直後の圧力上昇は小さいため, これらの圧力変化は燃 焼によるガス速度の增加によるるのではなく，レースウェ 亿奥に灰分が徐々に蓄積して形成された通気性不良のシェ 儿層の影響と考えられる。

また，実炉での炉芯ジンデ挿入時においても微粉炭吹き 込み時には，レースウェイ奥で挿入推力が上昇する傾向が 認められており 10$)$, 実炉でも同様に灰分の凝縮なぞ充填構造 の変化が生じているものと推測される。

$4 \cdot 2$ シェル形成によるガス流れ変化

微粉炭灰分由来のシェル層がレースウエイ近傍のガス流 れに大きく影響し，炉壁熱負荷を増大させているものと推 察されるが，さらにモデル計算で通気抵抗の大きいシェル 層の形成とガス流れの関係を検討した。

レースウェイ近傍における充壃構造とガス流れ变化との 関係を検討するために, 2 次元微粉炭燃焼モデル11)用いた。 Fig. 10 は $200 \mathrm{~kg} / \mathrm{t}$ の微粉炭吹き込み時におけるシェル層が存
在するケースと存在しないケースのガス流れベクトルの計 算結果を示す。レースウェイ近傍の空隙率には本园中に示す ように設定した。なお，Fig.8の結果を参考に，シェル層内 の空隙率をは内面を 0.3 , 外面を0.1として与元た。Fig.10よ り, シェル層の存在により，レースウェイから炉中心方向 へのガス流れが抑制され，レースウェイ上方へのガス流れ が強くなっていることがわかる。すなわち, 周辺流が強化 されている。Fig.11には羽口軸，および $1 \mathrm{~m}$ 上レベルにおけ るガス温度分布を示す。微粉炭吹き込みにより，炉壁付近 のガス温度は上昇するが，シェル層形成時には，炉壁近傍 の最高温度がさらに増加する。このようにして, 周辺流強 化，ガス温度上昇が熱輻射を介して炉壁熱負荷を増大させ ているものと推測される。

よって，以上のようなレースウェイ近傍のシェル層，す なわち通気性不良の領域生成が微粉炭多量吹き込2時に実 炉で観察される炉体熱負荷上昇の主因の一つと考元られ， 微粉炭多量吹き込2長期安定操業の実現のためには微粉炭 の燃焼率改善を同時に低灰分炭の使用，あるいは微粉炭灰 分の融点低下を目的としたフラックスの同時吹き込みなど シェル層の解消につながる方策も必要と思われる。またう ンスの位置も燃焼焦点に大きく影響する要因であり, 熱負 荷々燃焼率の両者の観点からランス位置を決定すべきと考 えられる。

\section{5. 結論}

コークス充填層型試験燃焼炉を用い，レースウエイ内お よび近傍での燃焼挙動，ガス流れ挙動と炉体熱負荷との関 係に注目した実験，モデル計算を行い，以下の知見を得た。

(1)微粉炭のレースウェイ内燃焼に和いて, 燃焼焦点, すなわち最高温度位置はガス組成中の $\mathrm{CO}_{2}$ 濃度のピークに対 応する。

(2) 燃焼焦点の位置は揮発分投入量に支配され，微粉炭 揮発分投入量の増大によって，燃焼焦点は羽口側に接近す る。 


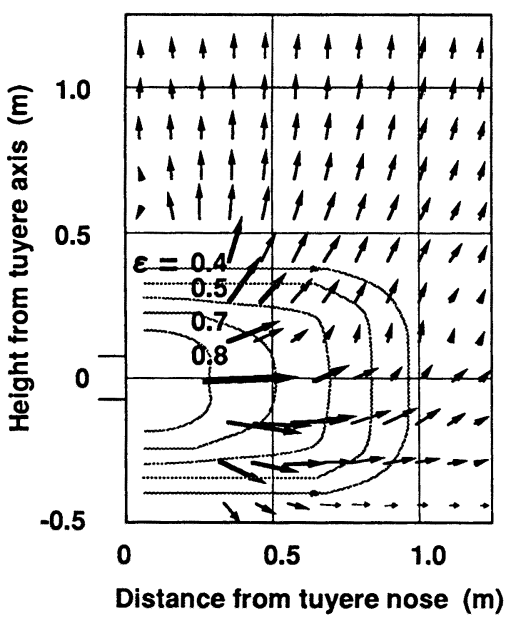

a) Without shell

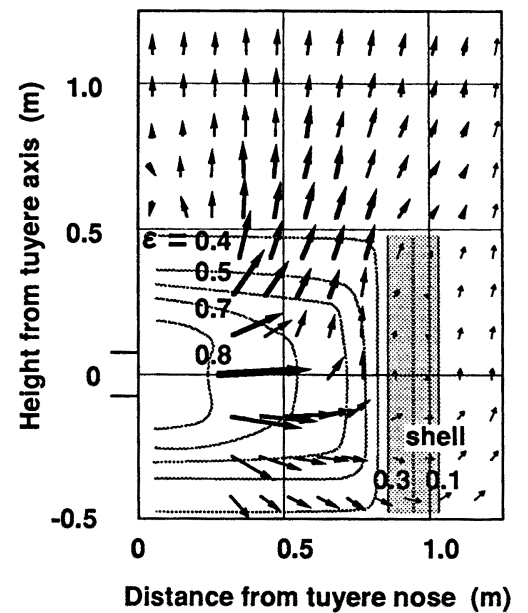

b) With shell

Fig. 10. Effect of shell formation on gas flow around the raceway by simulation model (PCR: $200 \mathrm{~kg} / \mathrm{t}$ ).

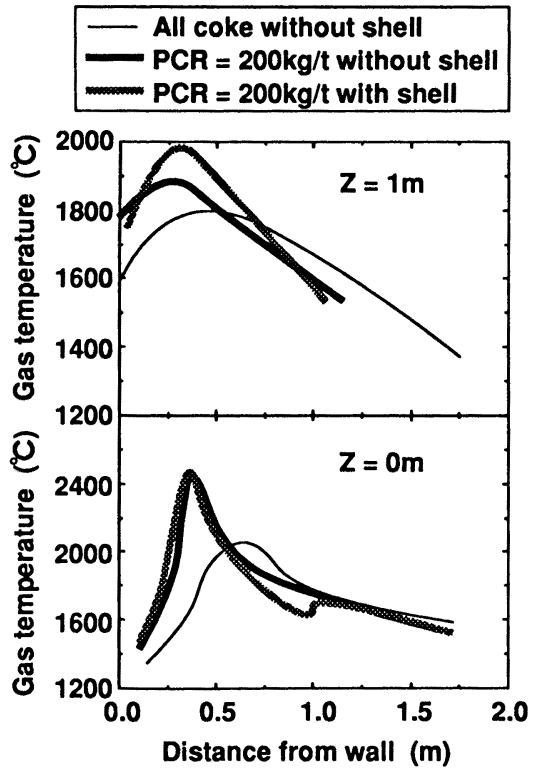

Fig. 11. Effect of shell formation on gas temperature around the raceway by simulation model ( $Z$ : Height from the tuyere axis).

（３）レースウエイ队燃烧摔は微粉荻中の捕発分荲の影響 を大きく受ける。

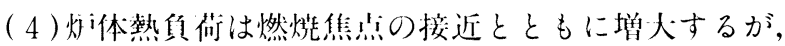
酸素富化，微粉荻中の炏分低トにより軽減する。

(5)微粉菼吹き迄及時にはレースウェイ奥に微粉炭中の
灰分に由来するシェル層が形成されこのシェル層により 周辺ガス流が強化され，炉壁熱負荷は增大する。しかし， 微粉炭中兏分量の低減はシェル層の形成を軽減し, 炉壁熱 真荷の上昇を抑制する。

(6)微粉炭多量吹き込みの達成のためには, 燃焼性を確 保しながら, 熱負荷上昇, 通気性覀化の要因を最大限, 排 除することが必要である。

\section{文献}

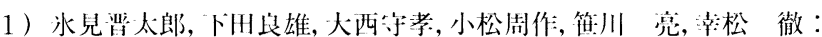
材料とプロセス, 5 (1992), p.115

2 ) 大鈴克-.., 北川修二, 失場用 武, 清水正賢，野間文雄：材料 プロセス， 4 (1991), p.100

3 ) 北野新治, 中矢 尚, 山形个郎, 奥旧哲决, 柴旧耕一郎, 後滕哲 也，伊藤占二，失場田 武：材料とプロセス， 7 (1994), p.124

4) 柿认一元，松永伸一，城本愛一郎，松岡裕㨁，1:野浩光，1111 应：材料とプロセス, 7 (1994), p.126

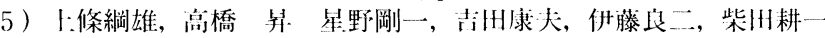
郎, 裕：材料とプロセス, 6 (1993), p.848

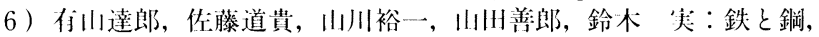
80 (1994), p.288

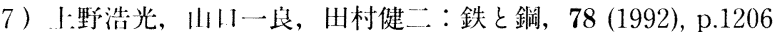

8 ) Y.de Lassat, G.Prado and O.Simonin : 49th Ironmaking Conf. Proceedings, AIME, (1990), p.473

9 ) 召川一也, 野沢健太郎, 上條綱雄, 你藤道貴, 川川裕一, 有川達 郎：材料とプロセス, 7 (1994), p.128

10) R.Murai, S.Kishimoto, H.Inoue, H.Mitsufuji, M.Sakurai and H.Wakai : The First Int.Cong. of Science and Technology of Ironmaking, Sendai, ISIJ, (1994), p.272

11）俈藤道貴，有川達郎，川川裕一，鈴木 笑，坪止考大：材料とプ ロセス, 7 (1994), p.958 